\title{
INFLUENCES OF RICE HUSK BIOCHAR (RHB) ON RICE GROWTH PERFORMANCE AND FERTILIZER NITROGEN RECOVERY UP TO MAXIMUM TILLERING STAGE
}

\author{
DENIEL S. ${ }^{1}$, ROSENANI A.B. ${ }^{1}$, AHMAD S.H. ${ }^{1}$, ABDUL RAHIM K.B. ${ }^{2}$ \\ ${ }^{1}$ Department of Soil Management, Faculty of Agriculture, Universiti Putra Malaysia, Malaysia \\ ${ }^{2}$ Division of Agrotechnology and Biosciences, Malaysian Nuclear Agency, Malaysia
}

\begin{abstract}
A pot study was carried out to investigate the effects of rice husk biochar addition on rice growth performance and fertilizer nitrogen recovery. The biochar effect was studied by using ${ }^{15} \mathrm{~N}$ labelled fertilizer urea $\left(10\right.$ atom $\left.\%{ }^{15} \mathrm{~N}\right)$, as isotopic tracer, until maximum tillering stage (75 days after sowing). Rice husk biochar (RHB) was applied at rates of $0,5,10$ and $20 \mathrm{Mg} \mathrm{ha}^{-1}$ and laid in randomized complete block design with four replications. The result showed that biochar application significantly improved soil chemical properties $(\mathrm{pH}$, total $\mathrm{C}$, total $\mathrm{N}$, and available $\mathrm{P}$ ) compared to control treatment. Biochar addition increased number of tiller and root dry matter weight up to 4\% and $35 \%$, respectively, compared to un-amended pot. Likewise, application of biochar significantly increased N, P and $\mathrm{K}$ uptake by 3\%,19\% and 33\%, respectively, as compared to the nutrient uptake from the control treatment. Biochar treatment had no significant impact on fertilizer nitrogen recovery in aboveground biomass, in the range of $41 \%$ and $42 \%$, in comparison to the control. However, nitrogen fertilizer recovery in soil significantly increased by $47 \%$ over the control at application rate of $20 \mathrm{Mg} \mathrm{ha}^{-1} \mathrm{RHB}$. Increased fertilizer $\mathrm{N}$ recovery in soil possibly reduced $\mathrm{N}$ losses to the environment from volatilization and denitrification processes. Total ${ }^{15} \mathrm{~N}$ fertilizer recovery also found increase at highest application of RHB biochar with an increment of $16 \%$. In general, addition of biochar appeared to enhance crop growth performance but its effect on fertilizer $\mathrm{N}$ recovery in plant requires further study up to maturity of rice plant.
\end{abstract}

Keywords: Rice husk biochar; ${ }^{15} \mathrm{~N}$ isotopic tracer, nitrogen recovery, organic soil, rice

\section{INTRODUCTION}

The Malaysia population growth is estimated at 31.7 million persons in 2016 (Department of Statistics Malaysia, 2016). To meet the challenges, more grains need to be produced with minimal environmental deterioration and fertilizer cost. The key factor which should be of concern is the efficient use of nitrogen $(\mathrm{N})$ fertilizer such as urea in rice cultivation in Malaysia. According to Liu et al., (2010a), the global average $\mathrm{N}$ efficiency rate of $59 \%$ indicated that nearly two-fifths of $\mathrm{N}$ inputs were lost in ecosystems by various ways. High $\mathrm{N}$ fertilizer rates applied in rice cultivation are due to high losses of $\mathrm{N}$ (mainly gaseous losses) which was earlier reported to be more than 55\% (Zhu and Chen 2002; Xu et al., 2012). Nitrogen losses are through $\mathrm{NH}_{3}$ volatilization and denitrification, leaching and

Correspondence Author: Rosenani Abu Bakar, Faculty of Agriculture, Universiti Putra Malaysia.

Email: rosenani@agri.upm.edu.my runoff with floodwater (Xing et al., 2002; Lin et al., 2007; Tian et al., 2007).

As reported by Fageria and Baligar (2001), low fertilizer nitrogen use efficiency in lowland rice might due to $\mathrm{N}$ loss from leaching, volatilization, surface runoff and denitrification in the soil-flood water system. Roelcke et al. (2004) and Zou et al. (2009) reported that higher $\mathrm{N}$ fertilizer application at rates of over $200 \mathrm{~kg} \mathrm{~N} \mathrm{ha}^{-1}$ were used for rice cultivation in eastern China so as to ensure high productivity. The optimum $\mathrm{N}$ rate for rice production is different across countries, such as $120 \mathrm{~kg} \mathrm{~N} \mathrm{ha}^{-1}$ in clay loam in Malaysia (Puteh et al., 2014), $175 \mathrm{~kg} \mathrm{~N} \mathrm{ha}^{-1}$ in clay loam soil of Pakistan (Manzoor et al., 2006), 150 to $250 \mathrm{~kg} \mathrm{~N} \mathrm{ha}^{-1}$ in soils of China (Peng et al., 2006), $122 \mathrm{~kg} \mathrm{~N} \mathrm{ha}^{-1}$ for Gangetic soils of India (Kumar et al., 2010). Thus, there has been increasing attention towards fertilizer $\mathrm{N}$ recovery, which is defined as the ratio of the $\mathrm{N}$ output or uptake by crops to fertilizer $\mathrm{N}$ input (Liu et al., 2010b; Qiao et al., 2012). 
Most recently attention has been given to the use of biochar in cultivation of crops including rice to reduce nutrient losses and improve yield. However, in Malaysia, documented reports on influence of biochar on $\mathrm{N}$ fertilizer recovery using ${ }^{15} \mathrm{~N}$ labelled fertilizer as isotopic tracer in rice is greatly lacking. According to Petter et al. (2016), application of biochar has improved the efficiency of $\mathrm{N}$ use in upland crops four times higher compared to un-amended plot. However, some studies showed that no significant effect was detected on the application of biochar toward fertilizer $\mathrm{N}$ recovery. Due to limited ${ }^{15} \mathrm{~N}$ labelled fertilizer, a pot experiment under controlled environment was carried out using the isotopic dilution technique ${ }^{15} \mathrm{~N}$-labelled fertilizer with aim of assessing the effectiveness of rice husk biochar (RHB) in improving fertilizer $\mathrm{N}$ (urea) uptake by rice (Oryza sativa) plant and retention in soil up to maximum tillering stage, 75 days after sowing (DAS).

\section{MATERIALS AND METHODS}

\section{Experimental site and soil characteristics}

A pot study was carried out at Field 10, Universiti Putra Malaysia (UPM), Selangor in a rain shelter. The soil used in this study was collected from Kampung Tengah, Pasir Panjang (3³5'27.6" N 10104'10.5" E), Selangor. Characteristics of the soil are as given in Table 1.

Table 1: Selected chemical properties of the soil before treatment and RHB properties $(n=3$

\begin{tabular}{|c|c|c|}
\hline Chemical properties & $\begin{array}{c}\text { Initial soil } \\
\text { (non-amended soil) }\end{array}$ & RHB \\
\hline $\mathrm{pH}($ soil $=1: 2.5 ;$ biochar $=1: 50)$ & 5.52 & 7.40 \\
\hline Total Carbon, (g kg-1) & 131.13 & 431.20 \\
\hline Total Nitrogen, (g kg-1) & 6.62 & 6.80 \\
\hline Available P, (mg kg-1) & 125.20 & - \\
\hline Extractable K, (mg kg-1) & 28.00 & - \\
\hline Extractable Ca, (mg kg-1) & 3221.40 & - \\
\hline Extractable Mg,(mg kg-1) & 156.00 & - \\
\hline CEC, $(\mathrm{cmol}(+) \mathrm{kg}-1)$ & 34.25 & - \\
\hline Total ash, $(\%)$ & - & 41.00 \\
\hline Volatile, $(\%)$ & - & 43.30 \\
\hline Total P, (g kg-1) & - & 1.55 \\
\hline Total K, (g kg-1) & - & 2.92 \\
\hline Total Ca, (g kg-1) & - & 0.85 \\
\hline Total Mg, (g kg-1) & - & 0.87 \\
\hline
\end{tabular}

- not determine

\section{Experimental layout and treatment}

The RHB used was collected from a small RHB producer, SENDI Enterprise at Sekinchan, Selangor. The experiment was laid out in a randomized complete block design with four biochar application rates $(0$, 5, 10 and $\left.20 \mathrm{Mg} \mathrm{ha}^{-1} \mathrm{RHB}\right)$. Each treatment was replicated four times. The RHB rates was selected according to the study conducted by Masulili et al. (2010) which also used a similar source of RHB in rice cultivation on acid sulphate soil, Kalimantan, Indonesia. The results showed that application of biochar seems to response with application of $5 \mathrm{Mg}$ $\mathrm{ha}^{-1}$ RHB and produce the maximum grain yield up to $10 \mathrm{Mg} \mathrm{ha}^{-1} \mathrm{RHB}$. Treatments were set up in slope-sided plastic pot $37.5 \mathrm{~cm}$ in height and $35 \mathrm{~cm}$ in diameter at the top and $26.5 \mathrm{~cm}$ at the base. Biochar was incorporated into soil two weeks before the rice seeds were sown. Twenty-one seeds of variety MR 263 was used and sown through direct broadcasting. After one week, thinning of seedlings was carried out to sixteen seedlings per pot based on calculation of field 
application where seeds were broadcasted at $200 \mathrm{~g}$ for $25 \mathrm{~m}^{2}$. The water depth was maintained at $5 \mathrm{~cm}$ above soil surface which started at 15 DAS and then drained at 7 days before harvesting at 75 DAS on the rice maximum tillering stage. Submerged soil $\mathrm{pH}$ and plant growth were recorded every 15 days starting from day 15 DAS to determine the effect of RHB amendment on soil $\mathrm{pH}$ and height improvement. Fertilization of rice crop was according to recommended rate and procedure by Malaysian Agricultural Research and Development Institute (MARDI). The ${ }^{15} \mathrm{~N}$-labelled urea (10\% atom excess) was used as the only chemical $\mathrm{N}$ fertilizer application and functioned as isotopic tracer. Fifteen days after sowing, $\mathrm{N}$ at rate of $70 \mathrm{~kg} \mathrm{~N}^{-1}\left(2.65 \mathrm{~g}{ }^{15} \mathrm{~N}\right.$ labelled urea pot $^{-1}$ ) was added as a basal dose. Likewise, triple super phosphate was applied at rate of $47.2 \mathrm{~kg} \mathrm{P} \mathrm{ha}^{-1}\left(1.0 \mathrm{~g} \mathrm{TSP} \mathrm{pot}^{-1}\right)$, while muriate of potash was applied at rate of $39 \mathrm{~kg} \mathrm{~K} \mathrm{ha}^{-1}$ $\left(0.62 \mathrm{~g} \mathrm{MOP} \mathrm{pot}^{-1}\right)$ at 3 different stages (15, 30 and 55 DAS).

\section{Soil sampling and analysis}

After harvest, the soil samples were collected at three different points using a small hand auger to determine the soil characteristics (soil $\mathrm{pH}$, total carbon (C), total $\mathrm{N}$, available phosphorus (P), extractable bases (potassium $(\mathrm{K})$, calcium $(\mathrm{Ca})$ and magnesium $(\mathrm{Mg})$ ) and cation exchange capacity (CEC) after harvest. The soil samples collected were air dried, ground and sieved $(\leq 2 \mathrm{~mm})$ before analysis. The soil $\mathrm{pH}\left(\mathrm{H}_{2} \mathrm{O}\right)$ was determined using a $\mathrm{pH}$ meter (Eijkelamp Waterproof Portable Meter 18.52.01) with 1:2.5 ratio soil solutions (with ionized water). Soil total C and total $\mathrm{N}$ were determined using dry combustion (Dumas method) using LECO TruMac CNS analyser (LECO TRuMac CNS Analyser). The soil available $\mathrm{P}$ was extracted based on Bray and Kurtz (1945) method. The extractable $\mathrm{P}$ concentration was determined using the Auto-analyser (AA; LACHAT Instrument QuickChem FIA+8000 SERIES). Soil extractable bases (K, Caand $\mathrm{Mg}$ ) and soil CEC was determined using ammonium acetate $\mathrm{pH} 7$ method. The soil exchangeable bases were determined using atomic absorption spectrophotometer (AAS, Perkin Elmer AAnalyist 400), while soil CEC was analysed using the Auto-analyser (AA).

\section{Plant tissue sampling and analysis}

The rice plants were harvested at 75 DAS. Biomass freshweight (DMWs), number of tillers (NT), root dry matter weight (DMWr) and plant height were recorded. After harvest, roots were washed free from the soil with a medium force spray of water to keep the root systems intact. The subsamples of plants and roots were then weighed and oven-dried for $72 \mathrm{~h}$ at $65{ }^{0} \mathrm{C}$ until it reached a constant weight. Dried plant samples were ground and sieved through $0.25 \mathrm{~mm}$ sieve and digested with wet digestion method (Wolf, 1982). Plant tissue was analysed for total $\mathrm{P}, \mathrm{K}, \mathrm{Ca}$ and $\mathrm{Mg}$ using AAS. Meanwhile, the total $\mathrm{N}$ of rice plant tissues was determined using LECO TruMac CNS analyser. Plant nutrients uptake was then calculated by multiplying the nutrient concentration obtained with the dry matter weight of rice crop.

For ${ }^{15} \mathrm{~N}$ analysis, an organic and inorganic nitrogen conversion using KjeldahlRittenberg method into nitrogen gas form is requisites for the determination of ${ }^{15} \mathrm{~N} /{ }^{14} \mathrm{~N}$ ratios in the plant and soil samples. The atom percentage of ${ }^{15} \mathrm{~N}$ of rice straw and soil were analysed using the optical emission spectrometer (Model NOI7 Fischer). The quantity of $\mathrm{N}$ derived from the labelled fertilizer (Ndff), $\mathrm{N}$ yield $(\mathrm{NU}),{ }^{15} \mathrm{~N}$ labelled fertilizer $\mathrm{N}$ yield (FNY) and $\mathrm{N}$ recovery using ${ }^{15} \mathrm{~N}$ labelled urea fertilizer in plants and soils are calculated according to the following equation:

\section{Percentage of ${ }^{15} \mathrm{~N}$ labelled fertilizer recovery in aboveground biomass}

Fraction of $\mathrm{N}$ derived from ${ }^{15} \mathrm{~N}$ labelled fertilizer $\left(\% N d f f_{\text {plant }}\right)$ is calculated as below:

$$
\% \text { Ndff plant }=\frac{\text { atom } \%{ }^{15} \mathrm{~N} \text { excess in above ground biomass }}{\text { atom } \%{ }^{15} \mathrm{~N} \text { excess fertilizer }} \times 100
$$




$$
\begin{aligned}
& \text { Total } \mathrm{N} \text { yield }\left(\mathrm{g} \mathrm{pot}^{-1}\right)=\% \mathrm{~N} \text { x Dry matter yield, }\left(\mathrm{g} \mathrm{pot}^{-1}\right) \\
& \mathrm{N} \text { fertilizer yield, }\left(\mathrm{g} \mathrm{pot}^{-1}\right)=\% \mathrm{Ndff} \mathrm{x} \text { Total } \mathrm{N} \text { yield, }\left(\mathrm{g} \mathrm{pot}^{-1}\right)
\end{aligned}
$$

\section{Percentage of ${ }^{15} \mathrm{~N}$ labelled fertilizer recovery in soil}

Fraction of ${ }^{15} \mathrm{~N}$ labelled fertilizer $\left(\% N d f f_{\text {soil }}\right)$ is calculated as below:

$$
\begin{aligned}
& \%{ }^{15} \mathrm{~N} \text { labelled fertilizer recovery } \\
& \text { in above ground biomass }
\end{aligned}=\frac{\text { Amount of } \mathrm{N} \text { fertilizer yield }}{\text { Amount of } \mathrm{N} \text { added to each pot }} \times 100
$$

Nitrogen recovery is a quantitative measure of the actual uptake of fertilizer $\mathrm{N}$ by the plant in relation to the amount of $\mathrm{N}$ added to the soil as fertilizer. A common form of expression of fertilizer $\mathrm{N}$ use efficiency (NUE) is plant recovery of the added fertilizer.

\section{Statistical analysis}

Data collected were analysed with SAS 9.1 software (SAS Institute Inc., USA). One-way analysis of variance (ANOVA) was performed to determine the significance effects of RHB treatments in crop growth parameters, soil properties and nitrogen recovery. The significant differences between means were determined by Least Significant Difference (LSD) test at $p \leq 0.05$. Single linear regression analysis was performed to examine the effect of RHB on rice yields, nutrient uptake and soil properties. Pearson correlation coefficients were calculated to determine the relationship between straw dry matter weight and soil properties, rice nutrient uptake using at $\mathrm{P}=0.05$ using SAS 9.2 software (SAS Institute Inc., USA).

\section{RESULTS}

\section{Effect of RHB amendment on soil chemical characteristics}

Table 2 represent the average of soil chemical properties as influenced by different RHB application ratesafter harvest. Biochar amendment significantly increased soil $\mathrm{pH}$ at all RHB application rates after harvest. Soil $\mathrm{pH}$ showed a tendency to increase with increasing biochar application rates and increased by 0.6 and 1.3 units, respectively, as compared to the treatment with no biochar. The highest soil $\mathrm{pH}$ value was observed in the pot treated with maximum biochar application rates, while the lowest value was recorded in the control pot. However, soil total $\mathrm{C}$ increased significantly only at application of $5 \mathrm{Mg} \mathrm{ha}^{-1} \mathrm{RHB}$ relative to control, while no significant changes was observed at rates of $10 \mathrm{Mg} \mathrm{ha}^{-1}$ and $20 \mathrm{Mg} \mathrm{ha}^{-1}$. In particular, compared to the corresponding control, soil total $\mathrm{N}$ significantly increased by $18 \%$ and $38 \%$ with application of 10 and $20 \mathrm{Mg}$ $\mathrm{ha}^{-1}$ RHB, respectively, in comparison to the corresponding control. Thus, the soil total $\mathrm{N}$ showed an increase in biochar treated pot with increasing rates of biochar application. Soil available $\mathrm{P}$ was significantly affected by all biochar application rates with an increment of $14 \%$ to $21 \%$ in comparison to control. The highest soil available $\mathrm{P}$ was observed in the pot with treatment of $5 \mathrm{Mg} \mathrm{ha}^{-1} \mathrm{RHB}$, while the lowest value was recorded in the control pot. As for soil extractable bases, biochar addition significantly increased soil extractable K only at high RHB application rate of $20 \mathrm{Mg} \mathrm{ha}^{-1}$ as compared to control pot, while did not change significantly at rate of $5 \mathrm{Mg} \mathrm{ha}^{-1}$ and $10 \mathrm{Mg}^{-}$ 1. However, no significant differences were observed in extractable bases (Caand $\mathrm{Mg}$ ) and soil CEC in biochar treated pot compared to untreated pot (Table 2). 
Table 2. Selected soil chemical properties as influenced by different RHB application ratesat harvest (75 DAS)

\begin{tabular}{|c|c|c|c|c|}
\hline \multirow{2}{*}{ Parameters } & \multicolumn{4}{|c|}{ Biochar rate, $\mathrm{Mg} \mathrm{ha}^{-1}$} \\
\hline & 0 & 5 & 10 & 20 \\
\hline pH & $5.41 b^{*}( \pm 0.06)$ & $5.88 \mathrm{a}( \pm 0.19)$ & $5.91 \mathrm{a}( \pm 0.19)$ & $6.09 \mathrm{a}( \pm 0.25)$ \\
\hline Total C, $\left(\mathrm{g} \mathrm{kg}^{-1}\right)$ & $144.4 \mathrm{~b}( \pm 11.92)$ & $157.3 \mathrm{a}( \pm 19.77)$ & $139.7 \mathrm{~b}( \pm 12.24)$ & $129.7 \mathrm{c}( \pm 11.51)$ \\
\hline Total $\mathrm{N},\left(\mathrm{g} \mathrm{kg}^{-1}\right)$ & $5.0 \mathrm{c}( \pm 0.50)$ & $5.3 \mathrm{c}( \pm 0.69)$ & $5.9 \mathrm{~b}( \pm 1.19)$ & $6.9 \mathrm{a}( \pm 0.80)$ \\
\hline Available $\mathrm{P},\left(\mathrm{mg} \mathrm{kg}^{-1}\right)$ & $132.34 \mathrm{~b}( \pm 6.87)$ & $159.43 \mathrm{a}( \pm 7.63$ & $156.32 \mathrm{a}( \pm 7.17)$ & $150.72 \mathrm{a}( \pm 8.67)$ \\
\hline Extractable $\mathrm{K},\left(\mathrm{mg} \mathrm{kg}^{-1}\right)$ & $33.54 \mathrm{~b}( \pm 4.90)$ & $37.46 \mathrm{~b}( \pm 1.57$ & $40.70 \mathrm{~b}( \pm 5.05)$ & $90.92 \mathrm{a}( \pm 0.30)$ \\
\hline Extractable $\mathrm{Ca},\left(\mathrm{mg} \mathrm{kg}^{-1}\right)$ & $1846 \mathrm{a}( \pm 79.12)$ & $1906 \mathrm{a}( \pm 151.70)$ & $1814 \mathrm{a}( \pm 107.41)$ & $1699 \mathrm{a}( \pm 50.25)$ \\
\hline Extractable $\mathrm{Mg},\left(\mathrm{mg} \mathrm{kg}^{-1}\right)$ & $150 \mathrm{a}( \pm 22.04)$ & $146 \mathrm{a}( \pm 17.95)$ & $149 \mathrm{a}( \pm 19.53)$ & $132 \mathrm{a}( \pm 10.27)$ \\
\hline $\mathrm{CEC},\left(\mathrm{cmol}(+) \mathrm{kg}^{-1}\right)$ & $29.55 \mathrm{a}( \pm 3.31)$ & $31.05 \mathrm{a}( \pm 2.87)$ & $31.23 \mathrm{a}( \pm 3.08)$ & $32.45 \mathrm{a}( \pm 2.84)$ \\
\hline
\end{tabular}

* Means with different letters indicates significantly difference between treatment at $p \leq 0.05$ level by lsd test and \pm value indicate mean standard deviation

\section{Influence of RHB on crop growth performance}

In this study, RHB application was observed to increase the DMWs, plant height and root dry matter weight (Table 3). Rice straw dry matter weight was significantly affected by biochar application rates of 10 and $20 \mathrm{Mg} \mathrm{ha}^{-1}$, but not in the $5 \mathrm{Mg} \mathrm{ha} \mathrm{h}^{-1} \mathrm{RHB}$, compared to corresponding control $(\mathrm{p} \leq 0.05)$. The highest DMWs were observed in the pot treated with 20 $\mathrm{Mg} \mathrm{ha}{ }^{-1} \mathrm{RHB}$ with an increment of $12 \%$ as compared to control pot which is recorded the lowest value of DMWs. As for number of tillers, it was increased significantly at all RHB application rates with an increment up to $12 \%$ as compared to the control treatment. A higher number of tiller was recorded at application rate of $5 \mathrm{Mg} \mathrm{ha}^{-1} \mathrm{RHB}$, whereas control recorded the lowest. However, a significant increase in plant height was observed only at harvest (75 DAS) compared to control treatment (Figure 1). As expected, DMWr with RHB treatment was statistically higher than those from the control $(p \leq 0.05)$, indicating that RHB amendment are essential for better root development with an increment up to $46 \%$. The highest DMWr was observed at application rate of $20 \mathrm{Mg} \mathrm{ha}^{-1} \mathrm{RHB}$, while control was recorded the lowest DMWr value.

Table 3. Effect of RHB amendment on shoot dry matter weight (DMWs), number of tiller and plant height

\begin{tabular}{cccc}
\hline \multirow{2}{*}{ Biochar rate, $\mathrm{Mg} \mathrm{ha}^{-1}$} & \multicolumn{3}{c}{ Parameters } \\
\cline { 2 - 4 } & DMWs, $\left(\mathrm{g} \mathrm{pot}^{-1}\right)$ & No. of tiller & Root dry weight, $(\mathrm{g})$ \\
\hline \multirow{2}{*}{0} & $44.62 \mathrm{~b}$ & $41.25 \mathrm{~b}$ & $21.82 \mathrm{c}$ \\
& $( \pm 0.89)$ & $( \pm 0.85)$ & $( \pm 2.54)$ \\
5 & $44.88 \mathrm{~b}$ & $46.25 \mathrm{a}$ & $25.78 \mathrm{~b}$ \\
& $( \pm 0.71)$ & $( \pm 0.96)$ & $( \pm 2.36)$ \\
10 & $49.97 \mathrm{a}$ & $44.75 \mathrm{a}$ & $29.15 \mathrm{ab}$ \\
& $( \pm 1.30)$ & $( \pm 1.29)$ & $( \pm 2.00)$ \\
20 & $50.02 \mathrm{a}$ & $42.50 \mathrm{a}$ & $31.87 \mathrm{a}$ \\
& $( \pm 1.64)$ & $( \pm 1.71)$ & $( \pm 1.87)$ \\
\hline
\end{tabular}

* Means with different letters indicates significantly difference between treatment at $p \leq 0.05$ level by lsd test and \pm value indicate mean standard deviation 


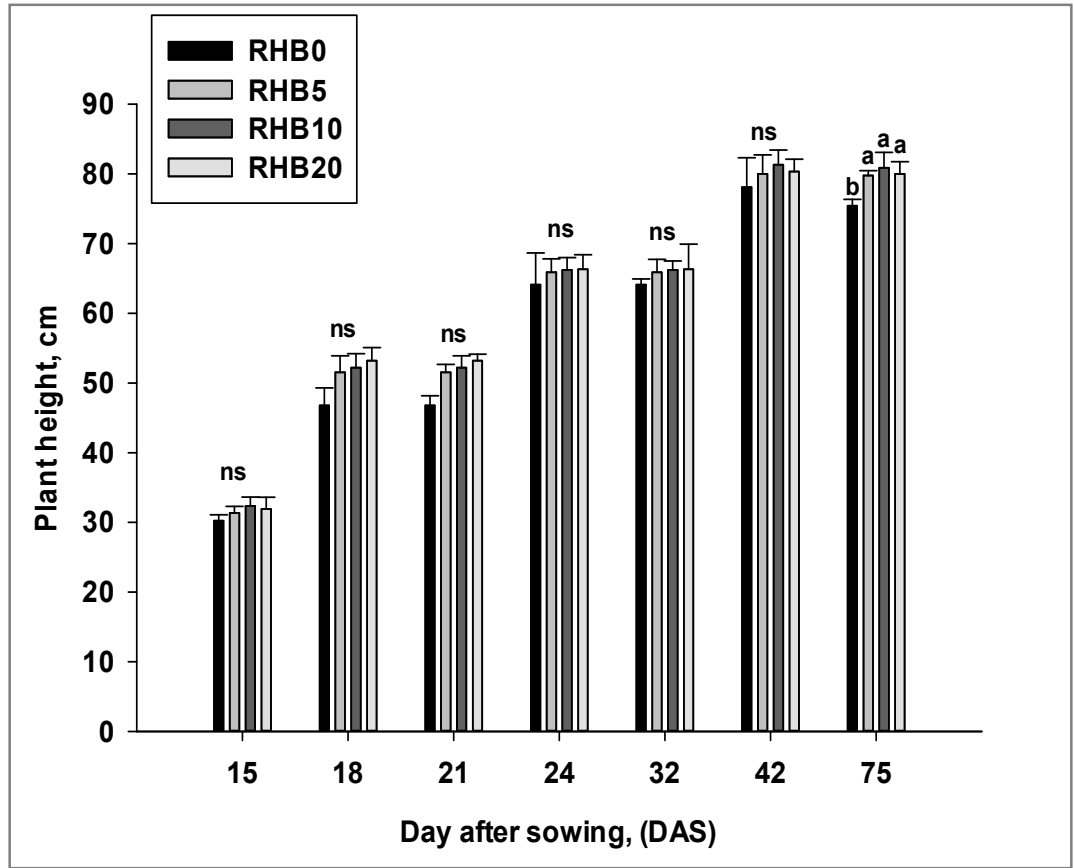

Figure 1: Plant height as affected by RHB application rates.

\section{Nutrient uptake responses with biochar amendment}

The pot study showed that N, P, K and Ca uptake statistically $(\mathrm{p}<0.05)$ improved as a result of biochar application compared to control treatment (Table 4). Nitrogen and phosphorus uptake significantly increased $(\mathrm{p} \leq 0.05)$ by RHB application at rates of 10 and $20 \mathrm{Mg} \mathrm{ha}^{-1}$, but not for $5 \mathrm{Mg} \mathrm{ha}^{-1}$ as compared to control treatment. The highest $\mathrm{N}$ and $\mathrm{P}$ uptake was recorded at $20 \mathrm{Mg} \mathrm{ha}^{-1} \mathrm{RHB}$ application rates with an increment of $7 \%$ and $30 \%$, respectively, compared to control which was recorded the lowest value. In particular, potassium uptake was significantly different at all RHB application rates as compared to control treatment. The $\mathrm{K}$ uptake showed a tendency to increase with increasing RHB application rate with the highest value was recorded at application of $20 \mathrm{Mg} \mathrm{ha}^{-1}$, whereas control was recorded the lowest. Additionally, $\mathrm{Ca}$ uptake was only significant $(\mathrm{p}<0.05)$ at application rate of $10 \mathrm{Mg} \mathrm{ha}^{-1}$, but not for 5 and $20 \mathrm{Mg} \mathrm{ha}^{-1}$ compared to corresponding control. However, RHB addition did not result in a significant change on $\mathrm{Mg}, \mathrm{Mn}, \mathrm{Zn}, \mathrm{Fe}$ and $\mathrm{Cu}$ uptake as compared to control treatment (Table 4).

Table 4. Rice shoot nutrient uptake as influenced by different RHB application rates

\begin{tabular}{|c|c|c|c|c|c|c|c|c|c|}
\hline \multirow{2}{*}{$\begin{array}{l}\text { Biochar rate, } \\
\text { Mg ha }^{-1}\end{array}$} & \multicolumn{9}{|c|}{ Nutrient uptake, $\mathrm{mg} \mathrm{pot}^{-1}$} \\
\hline & $\mathrm{N}$ & $\mathrm{P}$ & $\mathrm{K}$ & $\mathrm{Ca}$ & $\mathrm{Mg}$ & $\mathrm{Mn}$ & $\mathrm{Zn}$ & $\mathrm{Fe}$ & $\mathrm{Cu}$ \\
\hline \multirow[t]{2}{*}{0} & $692.13 c$ & $132.76 \mathrm{c}$ & $440.41 \mathrm{c}$ & $106.54 \mathrm{~b}$ & 105.05a & $14.48 \mathrm{a}$ & $6.22 \mathrm{a}$ & $35.36 a$ & $2.32 \mathrm{a}$ \\
\hline & $( \pm 2.47)$ & $( \pm 4.71)$ & $( \pm 56.36)$ & $( \pm 7.52)$ & $( \pm 2.59)$ & $( \pm 2.20)$ & $( \pm 1.35)$ & $( \pm 7.25)$ & $( \pm 2.18)$ \\
\hline \multirow[t]{2}{*}{5} & $703.03 \mathrm{bc}$ & $138.39 \mathrm{c}$ & $647.03 \mathrm{~b}$ & $106.12 \mathrm{~b}$ & $96.8 b c$ & $14.79 a$ & $5.21 \mathrm{a}$ & 35.81a & $1.96 a$ \\
\hline & $( \pm 6.66)$ & $( \pm 8.79)$ & $( \pm 66.21)$ & $( \pm 7.06)$ & $( \pm 6.73)$ & $( \pm 4.46)$ & $( \pm 0.14)$ & $( \pm 5.49)$ & $( \pm 0.62)$ \\
\hline \multirow[t]{2}{*}{10} & $714.40 \mathrm{~b}$ & $162.98 \mathrm{~b}$ & 769.09a & 116.15a & 102.16ab & $14.11 \mathrm{a}$ & $5.50 a$ & $32.85 a$ & $1.60 \mathrm{a}$ \\
\hline & $( \pm 15.24)$ & $( \pm 5.06)$ & $( \pm 47.03)$ & $( \pm 3.11)$ & $( \pm 4.29)$ & $( \pm 4.85)$ & $( \pm 0.66)$ & $( \pm 9.96)$ & $( \pm 1.39)$ \\
\hline \multirow[t]{2}{*}{20} & $740.45 a$ & 172.63a & $846.95 a$ & $94.98 \mathrm{c}$ & $94.13 c$ & $15.92 a$ & $5.07 a$ & $37.83 a$ & $1.87 a$ \\
\hline & $( \pm 6.29)$ & $( \pm 4.54)$ & $( \pm 42.00)$ & $( \pm 8.48)$ & $( \pm 8.55)$ & $( \pm 4.84)$ & $( \pm 0.68)$ & $( \pm 2.28)$ & $( \pm 0.38)$ \\
\hline
\end{tabular}

* Means with different letters indicates significantly difference between treatment at $p \leq 0.05$ level by lsd test and \pm value indicate mean standard deviation 


\section{Nitrogen components in aboveground biomass and soil as affected by RHB application}

The experimental results for nitrogen components in aboveground biomass and soil such as nitrogen derived from fertilizer ( $N d f f)$, nitrogen derived from soil $(N d f s)$, total $\mathrm{N}$ yield (TNY), fertilizer nitrogen yield (FNY), ${ }^{15} \mathrm{~N}$ labelled fertilizer recovery and total ${ }^{15} \mathrm{~N}$ labelled fertilizer recovery (TLFR) are summarized in Table 5. As for aboveground biomass, application RHB showed significant increase in $N d f_{S}$ only at application rate of $20 \mathrm{Mg} \mathrm{ha}^{-1}$, while no significant changes at application rate of $5 \mathrm{Mg} \mathrm{ha}^{-1}$ and $10 \mathrm{Mg} \mathrm{ha}^{-1}$ as compared to control treatment. The results obtained showed that RHB application rate of $10 \mathrm{Mg} \mathrm{ha}^{-1}$ and 20 $\mathrm{Mg} \mathrm{ha}{ }^{-1}$ significantly improved TNY in aboveground biomass by $3 \%$ and $7 \%$, respectively, compared to control treatment. However, there was no remarkable difference for $N d f f$, FNY and percent ${ }^{15} \mathrm{~N}$ labelled fertilizer recovery in aboveground biomass (AGLFR) as compared to control pot. As for soil, RHB application rate of $10 \mathrm{Mg} \mathrm{ha}^{-1}$ and $20 \mathrm{Mg}^{-}$ ${ }^{1}$ significantly increase TNY in soil with an increment of $18 \%$ and $37 \%$, respectively, as compared to control. Thus, soil TNY seems to increase with increasing rates of biochar. There was also a significant RHB effect on soil FNY under application rate of $20 \mathrm{Mg} \mathrm{ha}^{-1}$, while no statistically different at application rate of $5 \mathrm{Mg}$ $\mathrm{ha}^{-1}$ and $10 \mathrm{Mg} \mathrm{ha}^{-1}$ relative to control. Interestingly, at harvest percent ${ }^{15} \mathrm{~N}$ labelled fertilizer recovery in soil (SLFR) only showed positive response at higher RHB application at $20 \mathrm{Mg} \mathrm{ha}^{-1}$ with an increment of $47 \%$ in comparison to corresponding control. However, there were no significant changes in $N d f f$ and $N d f_{S}$ in soil. As for total ${ }^{15} \mathrm{~N}$ labelled fertilizer recovery, RHB application was only significantly difference at application rate of 20 $\mathrm{Mg} \mathrm{ha}{ }^{-1}$ as compared to control (Figure 2). However, total ${ }^{15} \mathrm{~N}$ fertilizer recovery seems to increase linearly with increasing RHB application rate.

Table 5. Influence of RHB amendment on $N d f f$, $N d f s, \mathrm{TNY}, \mathrm{TN}, \mathrm{FNY},{ }^{15} \mathrm{~N}$ labelled fertilizer recovery, and total ${ }^{15} \mathrm{~N}$ labelled fertilizer recovery in aboveground biomass and soil for rice

\begin{tabular}{|c|c|c|c|c|c|c|c|c|c|c|c|}
\hline \multirow[b]{2}{*}{$\begin{array}{c}\text { Biochar } \\
\text { rate (Mg } \\
\left.\text { ha }^{-1}\right)\end{array}$} & \multicolumn{5}{|c|}{ Above ground biomass } & \multicolumn{5}{|c|}{ Soil } & \multirow[b]{2}{*}{$\begin{array}{c}\text { Total }{ }^{15} \mathrm{~N} \\
\text { labelled } \\
\text { fertilizer } \\
\text { recovery, } \\
(\%)\end{array}$} \\
\hline & $\begin{array}{l}\text { Ndff, } \\
(\%)\end{array}$ & $\begin{array}{l}\text { Ndfs, } \\
(\%)\end{array}$ & $\begin{array}{l}\text { TNY, } \\
\text { (mg) }\end{array}$ & $\begin{array}{l}\text { FNY, } \\
\text { (mg) }\end{array}$ & $\begin{array}{c}{ }^{15} \mathrm{~N} \\
\text { labelled } \\
\text { fertilizer } \\
\text { recover } \\
\text { y (\%) }\end{array}$ & $\begin{array}{l}\text { Ndff, } \\
(\%)\end{array}$ & $\begin{array}{l}\text { Ndfs, } \\
(\%)\end{array}$ & $\begin{array}{l}\text { TNY, } \\
\text { (mg) }\end{array}$ & $\begin{array}{l}\text { FNY, } \\
\text { (mg) }\end{array}$ & $\begin{array}{c}{ }^{15} \mathrm{~N} \\
\text { labelled } \\
\text { fertilizer } \\
\text { recovery } \\
(\%)\end{array}$ & \\
\hline 0 & $\begin{array}{l}39.49 a \\
( \pm 0.92)\end{array}$ & $\begin{array}{l}60.51 \mathrm{~b} \\
( \pm 0.92)\end{array}$ & $\begin{array}{l}692.13 \mathrm{c} \\
( \pm 2.47)\end{array}$ & $\begin{array}{c}273 a \\
( \pm 6.28)\end{array}$ & $\begin{array}{l}40.97 a \\
( \pm 0.94)\end{array}$ & $\begin{array}{l}0.29 a \\
( \pm 0.02)\end{array}$ & $\begin{array}{l}99.71 a \\
( \pm 0.02)\end{array}$ & $\begin{array}{l}45.30 \mathrm{c} \\
( \pm 1.94)\end{array}$ & $\begin{array}{c}130 \mathrm{~b} \\
( \pm 14.68)\end{array}$ & $\begin{array}{l}19.42 \mathrm{~b} \\
( \pm 2.20)\end{array}$ & $\begin{array}{l}60.39 \mathrm{~b} \\
( \pm 1.54)\end{array}$ \\
\hline 5 & $\begin{array}{r}39.78 a \\
( \pm 0.38)\end{array}$ & $\begin{array}{l}60.22 b \\
( \pm 0.38)\end{array}$ & $\begin{array}{c}703.03 \mathrm{bc} \\
( \pm 6.66)\end{array}$ & $\begin{array}{c}279 a \\
( \pm 2.83)\end{array}$ & $\begin{array}{l}41.93 a \\
( \pm 0.42)\end{array}$ & $\begin{array}{c}0.27 a \\
( \pm 0.03)\end{array}$ & $\begin{array}{l}99.72 a \\
( \pm 0.04)\end{array}$ & $\begin{array}{l}48.33 c \\
( \pm 2.81)\end{array}$ & $\begin{array}{c}132 \mathrm{~b} \\
( \pm 9.07)\end{array}$ & $\begin{array}{l}19.83 \mathrm{~b} \\
( \pm 1.36)\end{array}$ & $\begin{array}{l}61.76 \mathrm{~b} \\
( \pm 1.53)\end{array}$ \\
\hline 10 & $\begin{array}{l}38.94 a \\
( \pm 0.25)\end{array}$ & $\begin{array}{l}61.07 \mathrm{~b} \\
( \pm 0.25)\end{array}$ & $\begin{array}{l}714.40 \mathrm{~b} \\
( \pm 15.24)\end{array}$ & $\begin{array}{c}278 a \\
( \pm 6.60)\end{array}$ & $\begin{array}{l}41.72 a \\
( \pm 0.99)\end{array}$ & $\begin{array}{c}0.25 a \\
( \pm 0.01)\end{array}$ & $\begin{array}{l}99.75 a \\
( \pm 0.01)\end{array}$ & $\begin{array}{l}53.30 \mathrm{~b} \\
( \pm 3.05)\end{array}$ & $\begin{array}{c}136 \mathrm{~b} \\
( \pm 11.09)\end{array}$ & $\begin{array}{l}20.34 \mathrm{~b} \\
( \pm 1.66)\end{array}$ & $\begin{array}{l}62.06 \mathrm{~b} \\
( \pm 0.77)\end{array}$ \\
\hline 20 & $\begin{array}{l}37.50 a \\
( \pm 0.30)\end{array}$ & $\begin{array}{l}62.50 \mathrm{a} \\
( \pm 0.30)\end{array}$ & $\begin{array}{l}740.45 a \\
( \pm 6.29)\end{array}$ & $\begin{array}{c}277 a \\
( \pm 2.55)\end{array}$ & $\begin{array}{l}41.64 a \\
( \pm 0.38)\end{array}$ & $\begin{array}{c}0.29 a \\
( \pm 0.04)\end{array}$ & $\begin{array}{l}99.70 a \\
( \pm 0.05)\end{array}$ & $\begin{array}{l}62.46 a \\
( \pm 3.45)\end{array}$ & $\begin{array}{c}191 a \\
( \pm 14.09)\end{array}$ & $\begin{array}{l}28.56 a \\
( \pm 5.62)\end{array}$ & $\begin{array}{c}70.2 \mathrm{a} \\
( \pm 5.44)\end{array}$ \\
\hline
\end{tabular}

* Means with different letters indicates significant difference between treatment at 0.05 level by lsd test and \pm value indic ate mean standard deviation. (Ndff: $N$ derived from ${ }^{15} N$ labelled fertilizer; TNY: Total $N$ yield; FNY: fertilizer $N$ yield). $\quad * N d f$; $N$ derived from soil. $* \% \mathrm{Ndfs}=100-\% \mathrm{Ndff}$ 


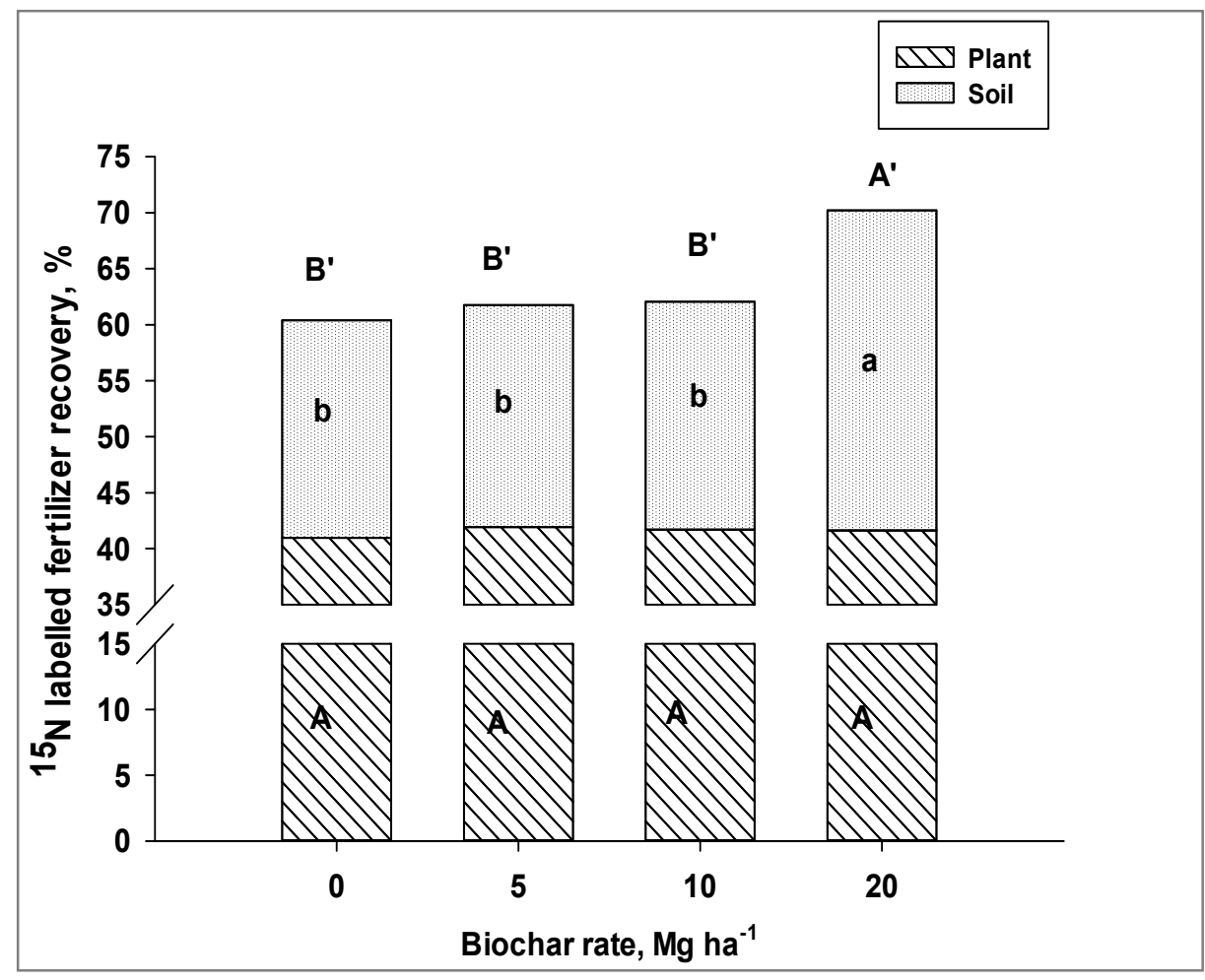

Figure 2: Changes of ${ }^{15} \mathrm{~N}$ labelled fertilizer recovery in plant and soil under RHB amendment.

\section{DISCUSSION}

The characteristic of the soil plays an important role to ensure the plant's ability to absorb water and nutrients for better crop growth performance. Soil $\mathrm{pH}$ was significantly higher in all biochar amended soils than control treatment (Table 2). Thus, it might attribute to the alkalinity of the biochar use in this experiment which leads to greater increase in soil $\mathrm{pH}$ compared with control treatment. Soil $\mathrm{pH}$ was significantly correlated with soil total $\mathrm{N}$ and available $\mathrm{P}$ also explains why soil $\mathrm{pH}$ was the highest when biochar was added (Table 1). Similar changes in soil $\mathrm{pH}$ as the result of biochar application have been reported in previous studies, i.e. acid sulfate soil using RHB in West Kalimantan, Indonesia (Masulili et al., 2010) and incubation study on acid Ultisol using plant material biochar such as canola, rice, corn, wheat, mung bean, peanut, soybean, pea and faba bean straw (Yuan et al., 2011).

The incorporation of RHB increased the soil total $\mathrm{C}$ (Table 2) $(\mathrm{p} \leq 0.05)$. The effect of biochar on soil total $\mathrm{C}$ might have occurred due to its high carbon content (413.23 $\mathrm{g} \mathrm{kg}^{-1}$, Table 1). The differences between biochar treatments in this experiment are contradicting the findings of Jien and Wang, (2013) who reported biochar application did not exhibit a significant increase in SOC level even though biochar high total $\mathrm{C}$ content (78.3\%). Additionally, application of RHB increased the soil total $\mathrm{N}$, which response can only be observed at higher RHB application $\left(10\right.$ and $\left.20 \mathrm{Mg} \mathrm{ha}^{-1}\right)$. This effect may attribute to high $\mathrm{N}$ content of RHB (Table 1). This improvement of soil total $\mathrm{N}$ with biochar addition is in concordance with study by Zhang et al., (2010), who reported increase in soil total $\mathrm{N}$ with wheat straw biochar on clay soil in Jiangxu Province, China. Meanwhile, soil available $\mathrm{P}$ under RHB amendment significantly higher compared to the corresponding control $(p<0.05)$. The positive increase in soil available $\mathrm{P}$ may be attributed to high $\mathrm{P}$ concentration in RHB ash content (Steiner et al., 2009) and direct $\mathrm{P}$ supplied from the RHB (Wu et al., (2014). 
Based on the results that has been obtained from this experiment, biochar application significantly increased root dry weight leading to the increased in straw dry matter weight and number of tiller (Table 3 ). The positive growth response might be attributed to the nutrient directly supplied by the biochar. This is in accordance with earlier studies that showed that an increases in root development in soils receiving rice-husk biochar treatment (Carter et al., 2013; Olmo et al., 2014). Positive yield as well as biomass responses resulting from biochar applications were reported repeatedly and attributed to various mechanisms, including the benefit from direct nutrient additions, improves nutrient availability, improves in root development, increases nutrient retention through higher exchange capacity, improves soil physical characteristics, and positive effects on soil microorganisms (Glaser et al., 2002; Lehmann and Rondon, 2006; Jeffery et al., 2010). A similar effect was also reported by studies done by Lehmann et al. (2003); Lehmann et al. (2006); Steiner et al. (2007); and Van Zwieten et al. (2010) and often showed much higher increase rates. For all RHB treatments, the rice straw dry matter weight was positively correlated with total ${ }^{15} \mathrm{~N}$ labelled fertilizer recovery, DMWr, soil $\mathrm{pH}$, soil total $\mathrm{C}$ and total $\mathrm{N}$, soil extractable $\mathrm{K}$, phosphorous and potassium uptake (Table 6). However, DMWr was positively correlated with soil $\mathrm{pH}$, soil total $\mathrm{N}$, available $\mathrm{P}$, soil extractable $\mathrm{K}$, phosphorus and potassium uptake.

Table 6. Coefficients of correlation for aboveground biomass ${ }^{15} \mathrm{~N}$ labelled fertilizer recovery, soil ${ }^{15} \mathrm{~N}$ labelled fertilizer recovery, total ${ }^{15} \mathrm{~N}$ labelled fertilizer recovery, soil properties $(\mathrm{pH}, \mathrm{TC}, \mathrm{TN}$, avai. $\mathrm{P})$, nutrient uptake (N, $\mathrm{P}, \mathrm{K})$ with four different $\mathrm{RHB}$ amendment rates

\begin{tabular}{|c|c|c|c|c|c|c|c|c|c|c|c|c|}
\hline & AGLFR & SLFR & TLFR & DMWr & Soil pH & $\begin{array}{l}\text { Soil } \\
\text { total c }\end{array}$ & $\begin{array}{c}\text { Soil } \\
\text { total N }\end{array}$ & Avai. P & $\begin{array}{c}\text { Soil } \\
\text { Extrac. } \\
\text { K }\end{array}$ & $\begin{array}{c}\mathrm{N} \\
\text { uptake }\end{array}$ & $\begin{array}{c}\mathrm{P} \\
\text { uptake }\end{array}$ & K uptake \\
\hline DMWs & $-0.009^{\text {ns }}$ & $0.487^{\mathrm{ns}}$ & $0.516^{*}$ & $0.683^{* *}$ & $0.622^{*}$ & $-0.673^{*}$ & $0.717^{* *}$ & $0.306^{\mathrm{ns}}$ & $0.716^{* *}$ & $0.343^{\mathrm{ns}}$ & $0.901^{* * *}$ & $0.761^{* *}$ \\
\hline AGLFR & & $0.103^{\text {ns }}$ & $0.190^{\text {ns }}$ & $0.265^{\text {ns }}$ & $0.305^{\text {ns }}$ & $0.188^{\text {ns }}$ & $0.167^{\mathrm{ns}}$ & $0.447^{\text {ns }}$ & $0.034^{\text {ns }}$ & $0.362^{\text {ns }}$ & $0.109^{\mathrm{ns}}$ & $0.488^{\mathrm{ns}}$ \\
\hline SLFR & & & $-0.651^{* *}$ & $0.471^{\text {ns }}$ & $0.224^{\mathrm{ns}}$ & $-0.582^{*}$ & $0.808^{* * *}$ & $0.184^{\text {ns }}$ & $0.779^{* * *}$ & $0.501^{*}$ & $0.585^{*}$ & $0.458^{\mathrm{ns}}$ \\
\hline TLFR & & & & $0.523^{*}$ & $0.304^{\mathrm{ns}}$ & $-0.553^{*}$ & $-0.553^{*}$ & $0.287^{\mathrm{ns}}$ & $0.783^{* * *}$ & $0.566^{*}$ & $0.639^{*}$ & $0.562^{*}$ \\
\hline DMWr & & & & & $0.656^{* * *}$ & $-0.290^{\mathrm{ns}}$ & $0.820^{* * *}$ & $0.593^{*}$ & $0.588^{*}$ & $0.481^{\text {ns }}$ & $0.717^{* *}$ & $0.811^{* * *}$ \\
\hline Soil pH & & & & & & $-0.277^{\mathrm{ns}}$ & $0.555^{*}$ & $0.601^{*}$ & $0.602^{*}$ & $0.520^{*}$ & $0.616^{*}$ & $0.849^{* * *}$ \\
\hline Soil TC & & & & & & & $-0.584^{*}$ & $0.116^{\mathrm{ns}}$ & $-0.760^{* * *}$ & $-0.348^{\text {ns }}$ & $-0.709^{* *}$ & $-0.424^{n s}$ \\
\hline Soil TN & & & & & & & & $0.336^{\mathrm{ns}}$ & $0.883^{* * *}$ & $0.704^{* *}$ & $0.839^{* * *}$ & $0.798^{* * *}$ \\
\hline Soil avai. P & & & & & & & & & $0.095^{\text {ns }}$ & $0.350^{\text {ns }}$ & $0.261^{\mathrm{ns}}$ & $0.603^{*}$ \\
\hline Soil extrac. $\mathrm{K}$ & & & & & & & & & & $0.655^{* *}$ & $0.821^{* * *}$ & $0.709^{* *}$ \\
\hline $\mathrm{N}$ uptake & & & & & & & & & & & $0.507^{*}$ & $0.694^{* *}$ \\
\hline P uptake & & & & & & & & & & & & $0.834^{* * *}$ \\
\hline
\end{tabular}

* Means with different letters indicates significant difference between treatment at 0.05 level by lsd test. (DMWs: Shoot dry matter weight; AGLFR: Aboveground biomass ${ }^{15} \mathrm{~N}$ labelled fertilizer recovery; SLFR: Soil ${ }^{15} \mathrm{~N}$ labelled fertilizer recovery; TLFR: Total ${ }^{15} N$ labelled fertilizer recovery; DMWr: Root dry matter weight; TC: Carbon; TN: Nitrogen; Avai. P: Available phosphorus; Extrac. K: Extractable potassium; P: phosphorus; K:Potassium).

Result obtained from this study indicated that RHB amendment could increase shoot N, $\mathrm{P}, \mathrm{K}$ and $\mathrm{Ca}$ uptake. Thus, addition of RHB amendment into agricultural soil also reported to improve nutrient contents in soil as $\mathrm{N}, \mathrm{P}$ and $\mathrm{K}$ which could enhance nutrient uptake and benefits the plant growth (Major et al., 2010). Apart from direct nutrient additions or nutrient retention with biochar application, it was also reported to enhance crop productivity through improving soil quality, including soil porosity (Zhang et al., 2010) and alteration of soil microbial population and functions (Pietikainen et al., 2000). However, no statistical significance was detected for $\mathrm{Mg}$ $\mathrm{Mn}$ and Zinc in this study, which was contrary with the results of (Maru et al., 2015). 
Nitrogen is one of the most important nutrients use for plant growth development. Plant mainly received nitrogen sources from fertilizer and soil, but also from $\mathrm{N}$ fixation by plant. The results obtained revealed the effect of biochar application are in accordance with previous studies which increase $\mathrm{N}$ availability to crops (Chan et al., 2007; Chan et al., 2008; Pan et al., 2009 ), $\mathrm{N}$ recovery and rice productivity in a long term monitored rice paddy in this same area (Pan et al., 2009) with biochar application. Furthermore, no significant difference in nitrogen recovery in aboveground biomass could be attributed to retention of $\mathrm{N}$ by biochar, volatilization of $\mathrm{NH}_{3}$, nitrification and denitrification (Liang et al., 2006; Steiner et al 2008; Cassman et al., 2012). However, the increased RHB application rates simultaneously increase soil $\mathrm{N}$ recovery (Table 5), which is an agreement with the previous studies (Clough and Condron, 2010; Cheng et al., 2012; Taghizadeh-Toosi et al., 2012) due to reduce $\mathrm{N}$ leaching and adsorb $\mathrm{NH}_{3}$ with biochar application. In this pot study, there was no leaching, thus, labelled fertilizer $\mathrm{N}$ unaccounted losses of 29.8 to $39.6 \%$ may be attributed $\mathrm{NH}_{3}$ volatilization and denitrification. Firestone et al, (1982) reported that 0 to $70 \%$ of applied fertilizer $\mathrm{N}$ was lost from agricultural soil due to crop management practices, soil chemical and physiological and climatic condition. In addition, total ${ }^{15} \mathrm{~N}$ labelled fertilizer recovery was positively correlated with DMWr, soil total $\mathrm{C}$ and $\mathrm{N}$, soil extractable $\mathrm{K}$ and nutrient uptake $(\mathrm{N}, \mathrm{P}, \mathrm{K})$.

\section{CONCLUSION}

Results indicate that RHB amendment enhanced fertilizer $\mathrm{N}$ recovery in soil by $47 \%$ which may be taken up by the plant at later stage of growth, but had no significant difference in fertilizer $\mathrm{N}$ recovery in aboveground biomass between with and without RHB. However, total ${ }^{15} \mathrm{~N}$ fertilizer recovery was only significantly affected at $20 \mathrm{Mg} \mathrm{ha}^{-1} \mathrm{RHB}$ application rate with an increment of $16 \%$. Also, application of RHB improved soil chemical properties such soil $\mathrm{pH}$, total $\mathrm{C}$, total $\mathrm{N}$, available $\mathrm{P}$ and extractable $\mathrm{K}$ of paddy soil. The RHB significantly increased shoot dry matter weight and root dry matter weight and N, P, and
$\mathrm{K}$ uptake by plant. Results of this study justified further investigation of the effect of RHB application on rice up to maturity stage.

\section{ACKNOWLEDGEMENT}

This study was funded by Ministry of Sciences, Technology and Innovation (MOSTI), Malaysia. We would like to express our appreciation to Universiti Putra Malaysia (UPM), Malaysian Agricultural Research and Development Institute (MARDI) and Malaysia Nuclear Agency for their technical support and advice. Many thanks also go to all students who assisted us in this study.

\section{REFERENCES}

Bray RH, Kurtz LT. 1945. Determination of total, organic, and available forms of phosphorus in soils. Soil science, 59(1): 3946.

Carter S, Shackley S, Sohi S, Suy TB, Haefele S. 2013. The impact of biochar application on soil properties and plant growth of pot grown lettuce (Lactuca sativa) and cabbage (Brassica chinensis). Agronomy, 3(2): 404418.

Cassman N, Prieto-Davó A, Walsh K, Silva GG, Angly F, Akhter S, Barott K, Busch J, McDole T, Haggerty JM, Willner D. 2012. Oxygen minimum zones harbour novel viral communities with low diversity. Environmental microbiology, 14(11): 30433065.

Chan KY, Van Zwieten L, Meszaros I, Downie A, Joseph S. 2008. Agronomic values of greenwaste biochar as a soil amendment. Soil Research, vol. 45(8): 629-634.

Chan KY, Van Zwieten L, Meszaros I, Downie A, Joseph, S 2008. Using poultry litter biochars as soil amendments. Soil Research, 46(5): 437-444.

Cheng Y, Cai ZC, Chang SX, Wang J, Zhang JB. 2012. Wheat straw and its biochar have contrasting effects on inorganic $\mathrm{N}$ retention and $\mathrm{N}_{2} \mathrm{O}$ production in a cultivated Black Chernozem. Biology and Fertility of Soils, 48(8): 941-946. 
Clough TJ, Condron LM. 2010. Biochar and the nitrogen cycle: introduction. Journal of Environmental Quality, 39(4): 1218-1223.

Department of Statistics Malaysia. 2016. Population distribution and basic demographic, Population and Demography. Accessed $\quad 18^{\text {th }} \quad$ October 2016, https://www.statistics.gov.my/index.php? $\mathrm{r}=\mathrm{c}$ olumn/cthemeByCat\&cat $=155 \&$ bul_id $=$ OW 1xdEVoY1JCS0hUZzJyRUcvZEYxZ̄z09\&m enu id=L0pheU43NWJwRWVSZklWdzQ4 TlhUUT09

Fageria NK, Baligar VC. 2001. Lowland rice response to nitrogen fertilization. Communications in Soil Science and Plant Analysis, 32(9-10): 1405-1429.

Firestone MK. 1982. Biological denitrification. In: Nitrogen inagricultural soils (ed. F.J. Stevenson), Agronomy Monograph. American Society of Agronomy. Madison, Wisconsin, pp. 289-326

Glaser B, Lehmann J, Zech W. 2002. Ameliorating physical and chemical properties of highly weathered soils in the tropics with charcoal-a review. Biology and fertility of soils, 35(4): 219-230.

Jeffery S, Verheijen FG, Van Der Velde M, Bastos AC. 2011. A quantitative review of the effects of biochar application to soils on crop productivity using meta-analysis. Agriculture, ecosystems and environment, 144(1): 175-187.

Jien SH, Wang CS. 2013. Effects of biochar on soil properties and erosion potential in a highly weathered soil. Catena, 110: 225-233

Kumar D, Devakumar C, Kumar R, Das A, Panneerselvam P, Shivay YS. 2010. Effect of neem-oil coated prilled urea with varying thickness of neem-oil coating and nitrogen rates on productivity and nitrogen-use efficiency of lowland irrigated rice under Indo-Gangetic plains. Journal of plant nutrition, 33(13): 1939-1959.

Lehmann J, Pereira da Silva J, Steiner C, Nehls T, Zech W, Glaser B. 2003. Nutrient availability and leaching in an archaeological Anthrosol and a Ferralsol of the Central Amazon basin: fertilizer, manure and charcoal amendments. Plant and soil, 249(2): 343-357.

Journal of Wetlands Environmental Management Vol 6, No 1 (2018) 32 - 44

http://dx.doi.org/10.20527/jwem.v5i2.108
Lehmann J, Rondon M. 2006. Bio-char soil management on highly weathered soils in the humid tropics. Biological approaches to sustainable soil systems, CRC Press, Boca Raton, FL, pp. 517-530.

Lehmann J, Gaunt J, Rondon M. 2006. Bio-char sequestration in terrestrial ecosystems-a review. Mitigation and adaptation strategies for global change, 11(2): 395-419.

Liang B, Lehmann J, Solomon D, Kinyangi J, Grossman J, O'neill B, Skjemstard JO, Thies J, Luiza FJ, Peterson J, Neves EG. 2006. Black carbon increases cation exchange capacity in soils. Soil Science Society of America Journal, 70(5): 1719-1730.

Lin DX, Fan XH, Hu F, Zhao HT, Luo JF. 2007. Ammonia volatilization and nitrogen utilization efficiency in response to urea application in rice fields of the Taihu Lake Region, China. Pedosphere, 17(5): 639-645.

Liu J, You L, Amini M, Obersteiner M, Herrero M, Zehnder AJ, Yang. H. 2010a. A highresolution assessment on global nitrogen flows in cropland. In Proceedings of the National Academy of Sciences, 107(17): 8035-8040.

Liu S, Qin Y, Zou J, Liu Q. 2010b. Effects of water regime during rice-growing season on annual direct $\mathrm{N}_{2} \mathrm{O}$ emission in a paddy ricewinter wheat rotation system in southeast China. Science of the Total Environment, 408(4): 906-913.

Major J, Rondon M, Molina D, Riha SJ, Lehmann J. 2010. Maize yield and nutrition during 4 years after biochar application to a Colombian savanna oxisol. Plant and soil, 333(1-2): 117-128.

Manzoor Z, Awan TH, Zahid MA, Faiz FA. 2006. Response of rice crop (super basmati) to different nitrogen levels. Journal of Animal Pl. Science, 16(1-2): 52-55.

Maru A, Haruna OA, Charles Primus W. 2015. Coapplication of chicken litter biochar and urea only to improve nutrients use efficiency and yield of Oryza sativa L. cultivation on a tropical acid soil. The Scientific World Journal, 2015. 
Masulili A, Utomo WH, Syechfani MS. 2010. Rice husk biochar for rice based cropping system in acid soil 1 . The characteristics of rice husk biochar and its influence on the properties of acid sulfate soils and rice growth in West Kalimantan, Indonesia. Journal of Agricultural Science, 2(1): 39-47

Olmo M, Alburquerque J A, Barrón V, Del Campillo MC, Gallardo A, Fuentes M, Villar R. 2014. Wheat growth and yield responses to biochar addition under Mediterranean climate conditions. Biology and Fertility of Soils, 50(8): 1177-1187.

Pan G, Zhou P, Li Z, Smith P, Li L, Qiu D, Zhang X, Xu X, Shen S. Chen X. 2009. Combined inorganic/organic fertilization enhances $\mathrm{N}$ efficiency and increases rice productivity through organic carbon accumulation in a rice paddy from the Tai Lake region, China. Agriculture, ecosystems and environment, 131(3): 274-280.

Peng S, Buresh RJ, Huang J, Yang J, Zou Y, Zhong, $\mathrm{X}$ Wang G, Zhang F. 2006. Strategies for overcoming low agronomic nitrogen use efficiency in irrigated rice systems in China. Field Crops Research, 96 (1): 37-47.

Petter FA, de Lima LB, Júnior BHM de Morais, LA, Marimon BS. 2016. Impact of biochar on nitrous oxide emissions from upland rice. Journal of environmental management, 169: 27-33.

Pietikäinen J, Kiikkilä O, Fritze H. 2000 Charcoal as a habitat for microbes and its effect on the microbial community of the underlying humus. Oikos, 89(2): 231-242.

Puteh AB, Mondal MMA. 2014. Growth and yield performance of rice as affected by nitrogen rate. Life Science Journal, 11(8): 653-655.

Qiao J, Yang L, Yan T, Xue F, Zhao D. 2012. Nitrogen fertilizer reduction in rice production for two consecutive years in the Taihu Lake area. Agriculture, Ecosystems \& Environment, 146(1): 103-112.
Roelcke M, Han Y, Schleef KH, Zhu JG, Liu G, Cai ZC Richter J. 2004. Recent trends and recommendations for nitrogen fertilization in intensive agriculture in Eastern China. Pedosphere, 14(4): 449-460.

Steiner C, Teixeira WG, Lehmann J, Nehls T, de Macêdo JLV, Blum WE, Zech W. 2007. Long term effects of manure, charcoal and mineral fertilization on crop production and fertility on a highly weathered Central Amazonian upland soil. Plant and soil, 291(1-2): 275-290.

Steiner C, Das KC, Garcia M, Förster B, Zech W. 2008. Charcoal and smoke extract stimulate the soil microbial community in a highly weathered xanthic Ferralsol. Pedobiologia, 51(5): 359-366.

Steiner C, Garcia M, Zech W. 2009. Effects of charcoal as slow release nutrient carrier on NPK dynamics and soil microbial population: pot experiments with ferralsol substrate. Amazonian dark earths: Wim Sombroek's vision, pp. 325-338.

Taghizadeh-Toosi A, Clough TJ, Sherlock RR, Condron LM., 2012. Biochar adsorbed ammonia is bioavailable. Plant and Soil, 350(1-2): 57-69.

Tian YH, Yin B, Yang LZ, Yin SX, Zhu ZL. 2007. Nitrogen runoff and leaching losses during rice-wheat rotations in Taihu Lake region, China. Pedosphere, 17: 445-456.

Van Zwieten L, Kimber S, Morris S, Chan KY, Downie A, Rust J, Joseph S, Cowie A. 2010. Effects of biochar from slow pyrolysis of papermill waste on agronomic performance and soil fertility. Plant and soil, 327(1-2): 235-246.

Wolf B 1982. A comprehensive system of leaf analyses and its use for diagnosing crop nutrient status. Communications in Soil Science and Plant Analysis, 13(12): 10351059.

Wu Y, Xu G, Shao HB. 2014. Furfural and its biochar improve the general properties of a saline soil. Solid Earth, 5(2): 665. 
Xing GX, Cao YC, Shi SL, Sun GQ, Du LJ, Zhu JG. 2002. Denitrification in underground saturated soil in a rice paddy region. Soil Biology and Biochemistry, 34(11): 1593-1598.

Xu G, Lv,Y, Sun,J, Shao H, Wei L. 2012. Recent advances in biochar applications in agricultural soils: benefits and environmental implications. CLEAN-Soil, Air, Water, 40(10): 1093-1098.

Yuan JH, $\mathrm{Xu}$ RK. 2011. The amelioration effects of low temperature biochar generated from nine crop residues on an acidic Ultisol. Soil Use and Management, 27(1): 110-115.
Zhang, A, Cui L, Pan G, Li L, Hussain Q, Zhan X, Zheng J, Crowley D. 2010. Effect of biochar amendment on yield and methane and nitrous oxide emissions from a rice paddy from Tai Lake plain, China. Agriculture, ecosystems and environment, 139(4): 469-475.

Zhu ZL, Chen DL. 2002. Nitrogen fertilizer use in China-Contributions to food production, impacts on the environment and best management strategies. Nutrient Cycling in Agroecosystems, 63(2): 117-127. 